\title{
Correction to: Molecular detection and identification of Culex flavivirus in mosquito species from Jeju, Republic of Korea
}

\author{
Shilpa Chatterjee ${ }^{1 \dagger}$, Choon-Mee Kim², Na Ra Yun ${ }^{1}$, Dong-Min Kim ${ }^{1 *}{ }^{*}$, Hyeon Je Song ${ }^{3 \dagger}$ and \\ Kyeoung A. Chung ${ }^{3}$
}

\section{Correction to: Virol J (2021) 18:150}

https://doi.org/10.1186/s12985-021-01618-9

Following publication of the original article [1], the authors realised that a few minor but necessary edits were needed to the text. Furthermore, the statement about Funding was inadvertently left out. Authors would like to apologise for the inconvenience and reassure the readers that the correction does not change the results of the study.

In the fifth paragraph of the Discussion, $C x$. pipiens has been corrected to $C x$. p. pallens, thus the first sentence now correctly reads:

In this study, we collected the mosquito samples and the most predominant mosquito species identified was Cx. p.pallens, which accounted for $77.2 \%$ of the total population of 1877 mosquitoes, followed by Aedes albopictus (8.7\%), Chinese Anopheles sinensis (4.9\%), and finally Culex tritaeniorhynchus (1.6\%), a vector of JEV.

In the eighth paragraph, $C x$. pipiens complex should be called $C x$ pipiens species instead, and this has been corrected.

An important statement about Funding should be added:

The original article can be found online at https://doi.org/10.1186/s12985021-01618-9.

*Correspondence: drongkim@chosun.ac.kr

†Shilpa Chatterjee and HyeonJe Song equally contributed to this work

${ }^{1}$ Department of Internal Medicine, College of Medicine, Chosun

University, 588 Seosuk-dong, Dong-gu, Gwangju 61453, Republic of Korea

Full list of author information is available at the end of the article
This research was supported by a grant from the Korea Health Technology R\&D Project through the Korea Health Industry Development Institute (KHIDI), funded by the Ministry of Health \& Welfare, Republic of Korea (Grant No. HI20C0369).

Authors are grateful to the funders for the support.

The original article has been corrected.

\section{Author details}

${ }^{1}$ Department of Internal Medicine, College of Medicine, Chosun University, 588 Seosuk-dong, Dong-gu, Gwangju 61453, Republic of Korea. ${ }^{2}$ Department of Premedical Science, College of Medicine, Chosun University, Gwangju, Republic of Korea. ${ }^{3}$ Department of Clinical Laboratory Science, Gwangju Health University, Gwangju, Republic of Korea.

Published online: 20 August 2021

\section{Reference}

1. Chatterjee $\mathrm{S}$, et al. Molecular detection and identification of Culex flavivirus in mosquito species from Jeju, Republic of Korea. Virol J. 2021;18:150. https://doi.org/10.1186/s12985-021-01618-9.

\section{Publisher's Note}

Springer Nature remains neutral with regard to jurisdictional claims in published maps and institutional affiliations.

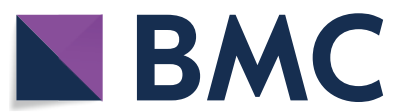

(c) The Author(s) 2021. Open Access This article is licensed under a Creative Commons Attribution 4.0 International License, which permits use, sharing, adaptation, distribution and reproduction in any medium or format, as long as you give appropriate credit to the original author(s) and the source, provide a link to the Creative Commons licence, and indicate if changes were made. The images or other third party material in this article are included in the article's Creative Commons licence, unless indicated otherwise in a credit line to the material. If material is not included in the article's Creative Commons licence and your intended use is not permitted by statutory regulation or exceeds the permitted use, you will need to obtain permission directly from the copyright holder. To view a copy of this licence, visit http://creativecommons.org/licenses/by/4.0/. The Creative Commons Public Domain Dedication waiver (http://creativecommons.org/publicdomain/zero/1.0/) applies to the data made available in this article, unless otherwise stated in a credit line to the data. 